\title{
Effects of Enriched Housing Design on Broiler Performance, Welfare, Chicken Meat Composition and Serum Cholesterol
}

\author{
Ulku Gulcihan Simsek ${ }^{\text {, Bestami Dalkilic² }}$, Mehmet Ciftci², Ibrahim Halil Cerci², \\ Muammer Bahsi ${ }^{3}$ \\ ${ }^{1}$ Department of Animal Science, ${ }^{2}$ Department of Animal Nutrition, Faculty of Veterinary Medicine, \\ ${ }^{3}$ Department of Biology, Faculty of Art and Science, University of Firat, Elazig-Turkey
}

Received April 10, 2008

Accepted December 15, 2008

\begin{abstract}
This experiment was conducted to determine the effects of enrichment housing design on performance, selected welfare indicators, chicken meat composition and serum cholesterol concentration of broiler chicken.

For this purpose, 480 Ross-308 chicks were assigned to two groups, Control and Test, each with 4 replications. The pens of the Test Group were enriched with perches and sand bedding. At the end of the study, 8 males and 8 females whose live weights were close to the group average from each group were slaughtered. Their blood was collected and serum was separated. For chemical analysis of the chicken meat, whole carcasses of 4 males and 4 females, and half of the breast and left thigh from the remaining 4 males and 4 females were collected. In the carcass group, whole carcass with its bones was minced, whereas in the other groups breast and tight meat were separated from the bones and minced in a meat grinder, homogenized with an electronic mixer, then flash frozen $\left(-40^{\circ} \mathrm{C}, 8-10 \mathrm{~h}\right)$ and stored $\left(-20^{\circ} \mathrm{C}, 3-4\right.$ weeks $)$ until analysed.

There was no significant difference between the groups in body weight, daily weight gain, feed intake, feed conversion and survivability. Litter moisture of the sand bedding was lower than that of the wood shavings. Contact dermatitis of hocks was reduced in the Test Group ( $P$ $<0.05)$. Length, width, bone mineral content (BMC) and bone mineral density (BMD) of the left tibiotarsus were similar between groups. The protein ratio of thigh meat was higher $(P<$ $0.01)$, and fat ratio of the meat was lower $(P<0.05)$ in the Test Group. Enriched housing design increased serum HDL cholesterol level and decreased thigh meat cholesterol level $(P<0.05)$.

In conclusion, it was found that housing enriched with perches and sand bedding in addition to wood shavings bedding improved broiler welfare and meat quality.
\end{abstract}

Broiler chickens, environmental enrichment, housing design, performance, welfare, meat quality, serum cholesterol

The appetite, feeding system, physical activity and genetic factors play important roles in fat storage (Hood 1983). Broiler chickens, depending on age and rearing conditions, spend most of the time resting (Weeks et al. 2000). There is a significant correlation between decreasing physical activity and adiposity (Ekelund et al. 2006). The lack of exercise is considered the main cause of leg weakness, and extreme durations of sitting on poor quality litter result in skin lesions on the breast and legs (Bessei 2006).

Enviromental enrichments can increase activity and thus improve both physical and psychological well-being. Maintaining balance while perching, and stepping onto and over perches exercise leg muscles and joints in a way that is different from simply walking. Wing and breast muscles are also utilized while walking and balancing on a perch (Newberry and Hall 1990; Le Van et al. 2000). Because of its attractiveness to broiler chickens for pecking and scratching behaviours, sand bedding could be utilized for exercise of body muscles (Shields et al. 2004). In addition to providing the birds with exercise, perching, pecking and scratching improve their welfare through providing an opportunity to perform natural behaviours (Newberry 1995), and could also improve performance, bone strength, and muscle condition, and decrease leg deformities (Balog et al. 1997; Shields et al. 2004; Le Van et al. 2000).

Address for correspondence:

Dr. U. Gulcihan Simsek

Department of Animal Science Faculty of Veterinary Medicine

University of Firat 23119 - Elazig

TURKEY
Phone: +90 $4242370000 / 3952$

Fax: +90 4242388173

E-mail:gsimsek@firat.edu.tr

http://www.vfu.cz/acta-vet/actavet.htm 
Keeping in view the above factors, the present study was performed to determine how the enrichment of housing with perches and sand bedding affects broiler performance, welfare, chicken meat composition and serum cholesterol level.

\section{Materials and Methods}

Experimental design

The study was carried out at a commercial broiler farm on a total of 480 Ross- 308 broiler chicks. Sex separation was performed by the wing feathering method. One-day-old broiler chicks were separated into a male group and a female group and kept in different pens for 3 days. On the fourth day, the chicks were weighed and divided among eight $4 \mathrm{~m}^{2}$ pens, each containing 60 birds $\left(15\right.$ broilers $\left./ \mathrm{m}^{2}\right)$ balanced according to body weight and sex.

There were two experimental treatments, Test and Control, each with 4 replicate pens. The Test and Control pens were arranged as shown in Fig. 1. As litter material, $5 \mathrm{~cm}$ thick wood shavings and sand were used in the Test Group and only wood shavings material was used in the Control Group. Each Test pen was separated into 3 sections by two $5 \mathrm{~cm}$-wide, $5 \mathrm{~cm}$-deep wooden perches set at a height of $5 \mathrm{~cm}$ during days 4-21 and increased to a height of $10 \mathrm{~cm}$ during days $21-42$. The doors of the pens were designed to be movable, so that bird density could be kept constant by movement of the doors, compensating for any mortality. Constant fresh air was provided in the pens through natural ventilation. In order to allow the heat to spread equally throughout the pens, a tube-shaped canvas system was used to deliver hot air to the poultry house. The temperature in the house was $23.21^{\circ} \mathrm{C}$, relative humidity was $65-75 \%$. The photoperiod and intensity of light were $24 \mathrm{~h} /$ day and 40 lux, respectively. Water and food were given ad libitum. Each pen provided equal feeder space $(4.4 \mathrm{~cm} / \mathrm{bird})$ from pan feeders and watering space $(1.5 \mathrm{~cm} / \mathrm{bird})$ from bell drinkers. Rations were prepared according to the National Research Council (1994) standards (Table 1).
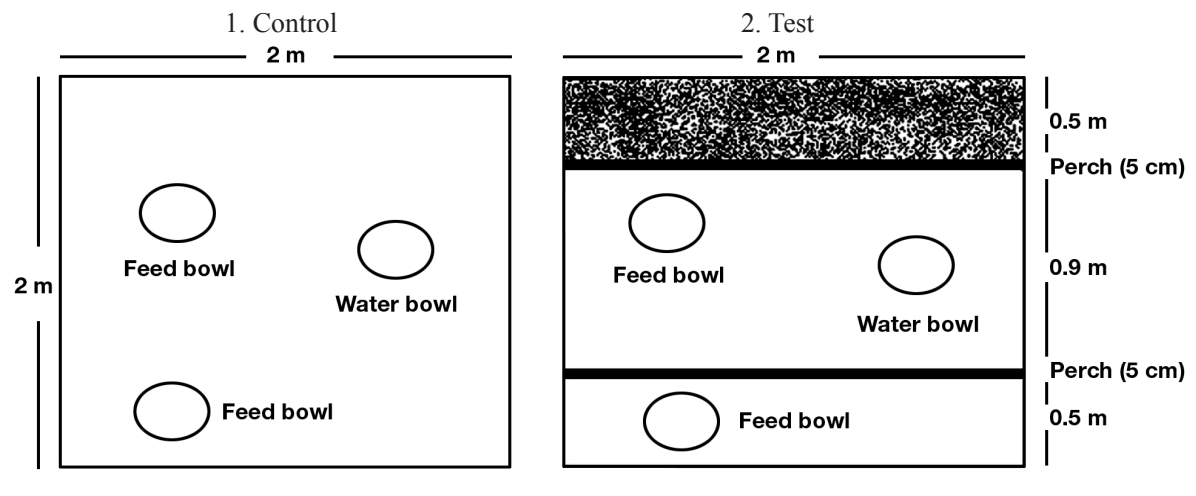

Wood shaving bedding

Sand bedding

Fig. 1. Housing design for the two treatment groups

At the end of the experiment ( $\left.42^{\text {nd }} d a y\right)$, the litter moisture was measured. Litter moisture measured the samples taken from four different parts of each pen as the sample weight difference after drying at $80^{\circ} \mathrm{C}$ for $24 \mathrm{~h} /$ original sample weight $\times 100$. Footpad and hock dermatitis, breast and hip lesions were assessed (no/yes coloration or lesion) in 10 male, and 10 female broilers, selected randomly from each pen. Bone properties were assessed in 4 males and 4 females whose body weights were close to the pen average. Eight males and 8 females whose body weights were close to the pen average were slaughtered. Their blood was collected and serum was separated. For chemical analysis of the meat, whole carcasses of four of the males and four of the females, and half of the breast and left thigh from the remaining 4 males and 4 females were collected. In the carcass group, whole carcass with its bones was minced, whereas in the other groups breast and thigh meat were separated from the bones and minced in a meat grinder, homogenized with an electronic mixer, then flash frozen $\left(-40{ }^{\circ} \mathrm{C}, 8-10 \mathrm{~h}\right)$ and stored $\left(-20{ }^{\circ} \mathrm{C}, 3-4\right.$ weeks $)$ until analysed.

Bone measurements

Length and width of the left tibiotarsus was measured with a digital compass. Bone mineral content (BMC) and bone mineral density (BMD) of the tibiotarsus were detected with a Lunar DPX (Lunar Corp., Madison, WI, USA, 1997) at the Nuclear Medicine Department of the Medicine Faculty at Firat University.

Chemical analysis

Nutrients in the feed (crude protein, fat, and ash) were determined according to methods defined in AOAC (1990) and crude cellulose level was measured (Crampton and Maynard 1938). Protein and fat content of total carcass, thigh and breast meat were also detected (AOAC 1990; Anonymous 1974). 
Table 1. Composition of the diets

\begin{tabular}{|c|c|c|c|}
\hline Feed Ingredients $(\mathrm{g} / 1000 \mathrm{~g})$ & 0 -14 days & 14-28 days & 28-42 days \\
\hline Corn & 458.69 & 364.82 & 497.05 \\
\hline Wheat & - & 150.00 & - \\
\hline Sunflower meal & - & - & 77.13 \\
\hline Soybean meal (44 CP) & 181.90 & 99.82 & - \\
\hline Full fat soybean & 250.00 & 260.00 & 300.00 \\
\hline Poultry by-products & 40.00 & 50.00 & 50.00 \\
\hline Meat and bone meal & 30.00 & 20.00 & 20.00 \\
\hline Vegetable oil & 13.04 & 23.67 & 28.64 \\
\hline Ground limestone & 3.12 & 6.10 & 3.83 \\
\hline Dicalcium phosphate & 11.14 & 10.61 & 10.31 \\
\hline $\mathrm{NaHCO}_{3}$ & 0.24 & 1.60 & 1.07 \\
\hline Salt & 1.92 & 1.36 & 1.70 \\
\hline DL-methionine & 3.28 & 3.38 & 2.94 \\
\hline L-lysine & 1.67 & 3.64 & 2.33 \\
\hline Choline & 1.00 & 1.00 & 1.00 \\
\hline Vitamin premix* & 1.50 & 1.50 & 1.50 \\
\hline Mineral premix ** & 1.00 & 1.00 & 1.00 \\
\hline Avatec & 0.50 & 0.50 & 0.50 \\
\hline Biacid & 1.00 & 1.00 & 1.00 \\
\hline Total & 1000 & 1000 & 1000 \\
\hline \multicolumn{4}{|c|}{ Nutritional composition ( $\%$ of the diet) } \\
\hline Dry matter & 88.82 & 87.74 & 87.55 \\
\hline Crude protein & 24.50 & 22.50 & 21.00 \\
\hline Crude fiber & 3.31 & 3.33 & 4.62 \\
\hline Ash & 6.34 & 6.02 & 5.64 \\
\hline Ether extract & 9.38 & 10.47 & 12.57 \\
\hline $\mathrm{Ca} * * *$ & 1.00 & 1.00 & 0.92 \\
\hline $\mathrm{P} * * *$ & 0.80 & 0.74 & 0.77 \\
\hline Methionine*** & 0.68 & 0.66 & 0.63 \\
\hline Lysine $* * *$ & 1.44 & 1.42 & 1.20 \\
\hline $\mathrm{ME}, \mathrm{Mcal} / \mathrm{kg}$ *** & 3.05 & 3.17 & 3.25 \\
\hline
\end{tabular}

*Vitamin premix supplied per kg; vitamin A $12000 \mathrm{IU}$; vitamin $\mathrm{D}_{3} 5000 \mathrm{IU}$; vitamin E $75 \mathrm{IU}$; vitamin $\mathrm{K}_{3} 3 \mathrm{mg}$; vitamin $\mathrm{B}_{1} 3 \mathrm{mg}$; vitamin $\mathrm{B}_{2} 6 \mathrm{mg}$; niacin $45 \mathrm{mg}$; calcium d-pantothenat $10 \mathrm{mg}$; vitamin $\mathrm{B}_{6} 7.5 \mathrm{mg}$; vitamin $\mathrm{B}_{12}$ $0.03 \mathrm{mg}$; folic acid $1 \mathrm{mg}$; d-biotin $0.15 \mathrm{mg}$

**Mineral premix supplied per 1 kg; Mn 100 mg; Fe 60 mg; Zn 60 mg; Cu 5 mg; Co 0.3 mg; I 1 mg; Se 0.35 mg

$* * *$ Calculated values

\section{Lipid extraction}

Extraction of lipid from tissue specimens was performed according to Hara and Radin (1978). For this purpose, a $1 \mathrm{~g}$ tissue specimen was homogenized in $10 \mathrm{ml}$ of a $3: 2(\mathrm{v} / \mathrm{v})$ hexane-isopropanol mixture for $30 \mathrm{~s}$. Tissue homogenate was centrifuged at $2,260 \mathrm{~g}$ for $10 \mathrm{~min}$; the supernatant was taken for analysis.

Analysis of cholesterol concentration by HPLC

Cholesterol analysis was carried out according to Katsanidis and Addis (1999). One portion of lipid extract was divided into two sections, put into tubes with caps, and 5\% KOH solution (prepared in $100 \%$ ethyl alcohol) was added. After mixing thoroughly, it was kept at $85^{\circ} \mathrm{C}$ for $15 \mathrm{~min}$. The tubes were cooled to room temperature, $5 \mathrm{ml}$ of distilled water was added and the fluid was vortexed. After phase separation, the upper hexane phase was taken and its solvent was evaporated. Then it was dissolved with nitrogen flow in an acetonitryl/methanol mixture $(50 \%+50 \%, \mathrm{v} / \mathrm{v})$, placed in autosampler vials, and prepared for analysis. For the mobile phase, acetonitryl/methanol $(60 \%+40 \%$, v/v) mixture was used. The mobile phase flow speed was $1 \mathrm{ml} / \mathrm{min}$. A UV detector was used for the analysis and wave length was $202 \mathrm{~nm}$. A Supelcosil LC 18 (15 $\times 4.6 \mathrm{~cm}, 5 \mu \mathrm{m}$; Sigma, USA) column was used. 
Detection of HDL cholesterol

An HDL cholesterol kit (Lot no: 4577, Olympus Diagnostica GmbH O'Callaghan's Mills, Co Clare, Ireland) was used for detection of HDL cholesterol level.

Statistical analysis

The data were analyzed using the General Linear Model (GLM) of SPSS 11.5 program for Windows (2002). Sex was included as a covariate and, for the reason, is not presented as a variable in the results. Food pad and hock dermatitis, and breast and hip lesions were analyzed by the Chi-square $\left(\chi^{2}\right)$ test. The results were considered as significant at $P<0.05$.

\section{Results}

The effects of enriched housing on performance indicators are shown in Table 2. There was no significant difference between groups in body weight, daily weight gain, feed intake, feed conversation or survivability $(P>0.05)$.

Table 2. The effects of enriched housing (Test group) on performance indicators in broilers $(\bar{x} \pm \bar{x} \mathrm{~S})$

\begin{tabular}{|c|c|c|c|}
\hline Measurements (g) & Control & Test & $P$ \\
\hline \multicolumn{4}{|l|}{ Body weight } \\
\hline $4 \mathrm{~d}$ & $79.20 \pm 1.80$ & $80.97 \pm 1.18$ & 0.42 \\
\hline $21 \mathrm{~d}$ & $656.69 \pm 8.19$ & $647.83 \pm 8.16$ & 0.44 \\
\hline $42 \mathrm{~d}$ & $2291.33 \pm 22.97$ & $2231.37 \pm 22.87$ & 0.06 \\
\hline \multicolumn{4}{|l|}{ Daily weight gain } \\
\hline $4-21 \mathrm{~d}$ & $33.96 \pm 0.87$ & $33.46 \pm 0.54$ & 0.64 \\
\hline $21-42 d$ & $77.83 \pm 1.14$ & $75.63 \pm 1.46$ & 0.28 \\
\hline \multicolumn{4}{|l|}{ Feed intake } \\
\hline $4-21 \mathrm{~d}$ & $55.91 \pm 2.74$ & $55.47 \pm 3.08$ & 0.91 \\
\hline $21-42 d$ & $141.65 \pm 2.79$ & $143.10 \pm 2.93$ & 0.72 \\
\hline \multicolumn{4}{|l|}{ Feed conversion } \\
\hline $4-21 \mathrm{~d}$ & $1.64 \pm 0.05$ & $1.65 \pm 0.06$ & 0.87 \\
\hline $21-42 d$ & $1.81 \pm 0.03$ & $1.89 \pm 0.02$ & 0.13 \\
\hline \multicolumn{4}{|l|}{ Survivability (\%) } \\
\hline $21 \mathrm{~d}$ & $99.66 \pm 0.33$ & $99.66 \pm 0.33$ & 1.00 \\
\hline $42 \mathrm{~d}$ & $98.99 \pm 0.66$ & $98.66 \pm 0.97$ & 0.78 \\
\hline
\end{tabular}

$P$ : significance, d: day

Treatment effects on some welfare indicators and bone structure of the tibia are shown in Table 3. It was observed that the sand bedding had lower litter moisture than the wood shavings. Hock dermatitis was decreased in the Test Group $(P<0.05)$.

Table 3. The effects of enriched housing (Test group) on some welfare indicators and bone structure of the tibiotarsus in broilers $(\bar{x} \pm \mathrm{S} \bar{x})$

\begin{tabular}{|l|c|c|c|}
\hline Measurements & Control & Test & $P$ \\
\hline Litter moisture (\%) & & & 0.70 \\
\hline Wood shaving litter & $21.49 \pm 2.16$ & $20.53 \pm 0.99$ & - \\
\hline Sand litter & - & $10.52 \pm 0.92$ & 0.29 \\
\hline Foot pad burns (\%) & 32.50 & 25.00 & 0.02 \\
\hline Hock burns (\%) & 25.00 & 11.25 & 0.26 \\
\hline Breast and hip lesions (\%) & 27.50 & 20.00 & 0.90 \\
\hline Tibiotarsus length $(\mathrm{cm})$ & $8.76 \pm 0.91$ & $8.77 \pm 0.91$ & 0.75 \\
\hline Tibiotarsus width $(\mathrm{cm})$ & $0.86 \pm 0.20$ & $0.88 \pm 0.43$ & 0.71 \\
\hline Tibiotarsus BMC level $(\mathrm{g})$ & $1.94 \pm 0.14$ & $2.01 \pm 0.09$ & 0.29 \\
\hline Tibiotarsus BMD level $\left(\mathrm{g} / \mathrm{cm}^{2}\right)$ & $0.12 \pm 0.00$ & $0.14 \pm 0.01$ & \\
\hline
\end{tabular}

BMC: bone mineral content, BMD: bone mineral density 
Table 4. The effects of enriched housing (Test group) on crude protein and fat (ether extract) values in raw meat of broilers $(\bar{x} \pm \mathrm{S} \bar{x})$

\begin{tabular}{|l|c|c|c|}
\hline Measurements $(\mathrm{g} / 100 \mathrm{~g})$ & Control & Test & $P$ \\
\hline Protein & & & \\
\hline Carcass & $16.88 \pm 0.33$ & $17.05 \pm 0.08$ & 0.61 \\
\hline Breast & $22.25 \pm 0.24$ & $22.77 \pm 0.34$ & 0.25 \\
\hline Thigh & $18.72 \pm 0.04$ & $19.39 \pm 0.09$ & $<0.01$ \\
\hline Fat & & & \\
\hline Carcass & $12.04 \pm 0.43$ & $11.00 \pm 0.27$ & 0.06 \\
\hline Breast & $2.80 \pm 0.22$ & $2.32 \pm 0.09$ & 0.09 \\
\hline Thigh & $6.85 \pm 1.38$ & $5.31 \pm 0.75$ & 0.03 \\
\hline
\end{tabular}

Table 5. The effects of enriched housing (Test group) on cholesterol levels in serum and meat of broilers $(\bar{x} \pm \mathrm{S} \bar{x})$

\begin{tabular}{|l|c|c|c|}
\hline & Control & Test & $P$ \\
\hline Serum $(\mathrm{mg} / \mathrm{ml})$ & & & \\
\hline Total cholesterol & $1.08 \pm 0.03$ & $1.01 \pm 0.03$ & 0.09 \\
\hline HDL & $0.70 \pm 0.03$ & $0.81 \pm 0.04$ & 0.04 \\
\hline Meat $(\mathrm{mg} / \mathrm{g})$ & & & \\
\hline Carcass & $1.74 \pm 0.04$ & $1.67 \pm 0.05$ & 0.32 \\
\hline Breast & $0.49 \pm 0.02$ & $0.40 \pm 0.04$ & 0.08 \\
\hline Thigh & $0.75 \pm 0.05$ & $0.56 \pm 0.07$ & 0.04 \\
\hline
\end{tabular}

The effects of enriched housing on crude protein and fat (ether extract) values in raw meat are shown in Table 4. Crude protein of thigh meat was higher $(P<0.01)$ and fat content of thigh meat was lower $(P<0.05)$ in the Test Group.

Table 5 shows the effects of enriched housing on cholesterol levels in serum and chicken meat. HDL cholesterol level of serum was higher $(P<0.05)$ and total cholesterol level of thigh meat was lower $(P<0.05)$ in the Test Group.

\section{Discussion}

The results of the present study are in agreement with previous studies in which the provision of perches did not affect body weight, feed conversion or mortality rate (PettitRiley and Estevez 2001; Estevez et al. 2002). However, body weight did tend to be lower in the Test Group of chickens compared to the control chickens in this study $(P=0.06)$, which is possibly related to increased physical activity required to cross perches to gain access to different parts of the pen. It is also possible that towards the end of the growth period the body weight could be adversely affected if the perches acted as barriers to movement when mobility was impaired by heavy body weight, resulting in uneven distribution of birds throughout the available space. Crowding in certain areas of the pen could make it more difficult for the birds to access feed and water, as well as to keep cool in hot weather.

Some authors have reported that exercise through perching and dustbathing improves leg condition and reduces leg problems in broiler chickens (Pettit-Riley and Estevez 2001; Shields et al. 2004). In the present study, broilers appeared to spend a lot of time on the sand bedding, which is a preferred litter for dustbathing (Petherick and Duncan 1989; Shields et al. 2004). Sand could be mixed easily and dried faster than wood shavings bedding, resulting in lower litter moisture content compared with the wood shavings bedding. The higher incidences of hock, footpad, breast and hip lesions are related to 
higher moisture levels and poorer quality of litter at high densities (Dozier et al. 2006). The study was carried out at optimum stocking density in broiler chickens (15 broilers $\left./ \mathrm{m}^{2}\right)$. In these environmental conditions the lower level of hock dermatitis in the Test Group was probably due to the reduced contact with poor quality litter when perching and when sitting on sand instead of wood shavings. While flying from the perch to floor, some birds may bump into bell drinkers, wetting the litter. Therefore, nipple drinkers may be used instead of bell drinkers.

Exercise can affect mineralization, structure and biomechanical properties of the growing bone (Huang et al. 2003). Higher body weights have been associated with increased weight, length and mineral content of the tibio-tarsal bone (Leterrier et al. 1998). Hughes et al. (1993) reported that tarso-metatarsal trabecular bone volume was greater in the laying hens with access to perches. In contrast, Tablante et al. (2003) determined that bone ash was not affected by the perch treatment in broiler chickens. Similarly, we did not observe a significant effect on the tibiotarsus length, width, bone mineral content or density in broilers of similar body weight in this study. It was thought that the production period, shape of the perch and using rate of this perch played an important role in bone mineralization.

A variety of effects of exercise and housing environment on fat metabolism have been reported in the literature. Ekelund et al. (2006) reported that there was a positive correlation between reduced physical activity and fat deposition in children, and Askew and Hecker (1976) detected that physical activity reduced fat cell diameter in the rats. SchrauwenHinderling et al. (2003) determined that long-term physical activity in humans increased lipolysis significantly, and that muscle load was important in lipolysis, and lipolysis was more pronounced in active muscles than inactive muscles. In chickens, Castellini et al. (2002) found that lipid ratios were decreased significantly in breast meat and drumsticks in an organic production system compared to a conventional broiler production system, and Zhan et al. (2007) reported that an increase in fat was associated with decreased protein in broiler meat. Our results are consistent with these reports. We found that enriched housing significantly reduced fat deposition in thigh meat in the Test Group, and tended to do so in breast meat, which may be explained by increased physical activity of legs and wings when climbing over perches, when dustbathing, and when foraging (pecking and scratching) in good quality litter. The effect on thigh meat, specifically, suggests that the muscle load plays an important role in fat deposition in broilers. The increased protein : fat ratio of thigh meat in our Test Group is in agreement with Zhan et al. (2007).

Deshaies et al. (1983) reported that increased activity did not affect serum total cholesterol values but did increase the HDL/total cholesterol ratio by $15 \%$ in rats. Furthermore, activity did not affect plasma cholesterol and triglyceride levels but did affect the distribution of cholesterol to HDL types in pigs (Stucchi et al. 1991). In agreement with these results, enriched housing in our study increased broiler serum HDL cholesterol; whereas serum total cholesterol was similar between groups. Ozbey and Esen (2007) reported that there was a significant reduction in the serum total cholesterol concentration of rock partridges kept on the ground compared with in cages.

Tho mas et al. (1977) reported that muscle cholesterol levels were significantly decreased with increased physical activity in humans, which corresponds to our finding that the total cholesterol level of thigh meat was reduced in our Test Group, suggesting that increased physical activity decreased total cholesterol level of thigh meat and that the muscle load was important in cholesterol synthesis. Our housing system including perches and sand bedding acted on breast muscles: this activity reduced slightly the total cholesterol level of breast meat $(P=0.08)$.

In conclusion, the enriched housing design used in this study appears to have stimulated activity without significantly affecting performance indicators, although the near-significant effect on the body weight at $42 \mathrm{~d}$ suggests that removal of the perches may be advisable 
near the end of the growing period to facilitate an even distribution of birds throughout the available space. The enriched housing improved broiler welfare as indicated by reduced hock dermatitis, as well as by providing an opportunity for the birds to engage in perching behaviour and by providing them with a choice of substrates for engaging in foraging, dustbathing and resting. However, given the benefits of sand on litter quality, it may be preferable for bird welfare to provide sand over the entire floor rather than providing a choice of bedding types. No adverse effects of the enrichments on bird health were observed. Given that animal numbers per square metre significantly affect profitability, it is notable that animal welfare and meat quality can be improved by environmental enrichment while maintaining a constant stocking density.

\section{Vliv obohaceného ustájení na užitkovost, welfare, složení masa a koncentraci cholesterolu v krevním séru brojlerů}

V pokusu byl sledován vliv obohacení životních podmínek chovu na užitkovost, vybrané ukazatele welfare, dále na složení masa a koncentraci cholesterolu v krevním séru brojlerových kuřat.

Kuřata brojlerů Ross - 308 ( $\mathrm{n}=480)$ byla rozdělena do dvou skupin, pokusné a kontrolní, každé ve 4 podskupinách. Chovné klece pro pokusné skupiny byly obohaceny hřady a pískovou podestýlkou. Na konci pokusu bylo z každé skupiny vybráno 8 kohoutků a 8 kuřiček, jejichž hmotnost se blížila průměrné hmotnosti jedinců v dané skupině, která byla poražena. Z odebraných vzorků krve bylo získáno sérum. Na chemický rozbor kuřecího masa byla odebrána jatečná těla 4 kohoutků a 4 kuřiček, ze zbývajících 4 kohoutků a 4 kuřiček z dané skupiny byla odebrána polovina prsní svaloviny a levé stehno. Odebraná celá jatečná těla byla rozdrcená včetně kostí a homogenizována, zatímco vzorky prsní a stehenní svaloviny byly rozemlety a homogenizovány bez kostního podkladu v elektrickém mixéru. Dále byly vzorky prudce zamraženy $\left(-40^{\circ} \mathrm{C}, 8-10 \mathrm{~h}\right)$ a uchovány $\left(-20{ }^{\circ} \mathrm{C}, 3-4\right.$ týdnů) do analýzy.

Mezi pokusnými a kontrolními skupinami nebyly zjištěny statisticky významné rozdíly $\mathrm{v}$ tělesné hmotnosti, denním prŕrůstku, př́ijmu krmiva, konverzi krmiva ani počtu úhynů. Písková podestýlka vykazovala nižší vlhkost než podestýlka z pilin. Výskyt kontaktní dermatitidy $\mathrm{v}$ bércové části končetin byla snížená v pokusné skupině $(P<0.05)$. Délka a šířka kostí, obsah minerálních látek v kostní hmotě (BMC) a minerální hustota kostní hmoty (BMD) získané rozborem levého tibiotarsu byla ve všech skupinách srovnatelná. V pokusné skupině byl vyšší podíl proteinu ve stehenní svalovině $(P<0.01)$, a procento tuku masa bylo nižší $(P<0.05)$. Zlepšení životních podmínek chovu vedlo ke zvýšení sérové koncentrace HDL cholesterolu a ke snížení koncentrace cholesterolu $(P<0.05)$ ve stehenní svalovině.

Z našich výsledků vyplývá, že obohacení životních podmínek chovu brojlerů o hřady a pískovou podestýlku, doplňující pilinovou podestýlku, zlepšilo užitkovost brojlerů a kvalitu jejich masa.

\section{Acknowledgement}

We would like to thank to OZNESIL Corp. for the opportunity to carry out the study.

\section{References}

Anonymous 1974: Et ve et mamulleri toplam yă̆ miktari tayini. (In Turkish, Detection of total fat amount in meat and meat products) TS 1744. Türk Standartlari Enstitüsü, Ankara

AOAC 1990: Official methods of analysis. $15^{\text {th }}$ ed. Association of official analytical chemists, Arlington, Virginia

Askew EW, Hecker AL 1976: Adipose tissue cell size and lipolysis in the rat: response to exercise intensity and food restriction. J Nutr 106: 1351-1360

Balog JM, Bayyari GR, Rath NC, Huff WE, Anthony NB 1997: Effect of intermittent activity on broiler production parameters. Poult Sci 76: 6-12 
Bessei W 2006: Welfare of broilers: a review. Worlds Poult Sci J 62: 455-466

Castellini C, Mugnai C, Dal Bosco A 2002: Effect of organic production system on broiler carcass and meat quality. Meat Sci 60: 219-225

Crampton EW, Maynard LA 1938: The relation of cellulose and lignin content to nutritive value of animal feeds. J Nutr 15: 383-395

Deshaies Y, LeBlanc J, Richard D 1983: Influence of palatable, high-fat diet, and exercise training on the highdensity lipoprotein to total cholesterol ratio in the rat. Metabolism 32: 62-65

Dozier WA, Thaxton JP, Purswell JL, Olanrewaju HA, Branton SL, Roush WB 2006: Stocking density effects on male broilers grown to 1.8 kilograms of body weight. Poult Sci 85: 344-351

Ekelund U, Brage S, Froberg K, Harro M, Anderssen SA, Sardınha LB, Riddoch C, Andersen LB 2006: TV viewing and physical activity are independently associated with metabolic risk in children: the European youth heart study. Plos Med 3: e-488

Estevez I, Tablante N, Pettit-Riley RL, Carr L 2002: Use of cool perches by broiler chickens. Poult Sci 81: 62-69

Hara A, Radin NS 1978: Lipid extraction of tissues with the low-toxicity solvent. Anal Biochem 90: 420-426

Hood RL 1983: Changes in fatty acid synthesis associated with growth and fattening. Proc Nutr Soc 42: 303-313

Huang TH, Lin SC, Chang FL, Hsieh SS, Liu SH, Yang RS 2003: Effects of different exercise modes on mineralization, structure and biomechanical properties of growing bone. J Appl Physiol 95: 300-307

Hughes BO, Wilson S, Appleby MC, Smith SF 1993: Comparison of bone volume and strength as measures of skeletal integrity in caged laying hens with access to perches. Res Vet Sci 54: 202-206

Katsanidis E, ADDIS PB 1999: Novel HPLC analysis of tocopherols, tocotrienols and cholesterol in tissue. Free Radic Biol Med 27: 1137-1140

Le Van NF, Estevez I, Stricklin WR 2000: Use of horizontal and angled perches by broiler chickens. Appl Anim Behav Sci 65: 349-365

Leterrier C, Rose N, Constantin P, NYS Y 1998: Reducing growth rate of broiler chickens with a low energy diet does not improve cortical bone quality. Br Poult Sci 39: 24-30

Newberry RC 1995: Enviromental enrichment: increasing the biological relevance of captive environments. Appl Anim Behav Sci 44: 229-243

Newberry RC, Hall JW 1990: Use of pen space by broiler chickens: effects of age and pen size. Appl Anim Behav Sci 25: $125-136$

National Research Council (NRC) 1994: Nutrient requirements of poultry. $9^{\text {th }}$ rev. ed. NRC. National Academy Press, Washington, DC, USA

Özbey O, Esen F 2007: The effects of breeding systems and stocking density on some blood parameters of rock partridges (Alectoris graeca). Poult Sci 86: 420-422

Petherick JC, Duncan IJH 1989: Behaviour of young domestic fowl directed towards different substrates. Br Poult Sci 30: 229-238

Pettit-Riley R, Estevez I 2001: Effects of density on perching behavior of broiler chickens. Appl Anim Behav Sci 71: $127-140$

Schrauwen-Hinderling VB, Van Loon LJC, Kopman R, Nicolay K, Saris WH, Kooi ME 2003: Intramyocellular lipid content is increased after exercise in nonexercising human skeletal muscle. J Appl Physiol 95: $2328-2332$

Shields SJ, Garner JP, Mench JA 2004: Dustbathing by broiler chickens: a comparison of preference for four different substrates. Appl Anim Behav Sci 87: 69-82

SPSS Inc. 2002: SPSS for Windows Release 11.5 (6 September 2002). Standard version

Stucchi AF, Terpstra AH, Foxall TL, Nicolosi RJ, Smith SC 1991: The effect of exercise on plasma lipids and LDL subclass metabolism in miniature swine. Med Sci Sports Exerc 23: 552-561

Tablante N L, Estevez I, Russek-Cohen E 2003: Effect of perches and stocking density on tibial dyschondroplasia and bone mineralization as measured by bone ash in broiler chickens. J Appl Poult Res 12: 53-59

Thomas TR, Londeree BR, Gerhardt KO, Gehrke CW 1977: Fatty acid profile and cholesterol in skeletal muscle of trained and untrained men. J Appl Physiol 43: 709-713

Weeks CA, Danbury TD, Davies HC, Hunt P, Kestin SC 2000: The behaviour of broiler chickens and its modification by lameness. Appl Anim Behav Sci 67: 111-125

Zhan XA, Wang M, Ren H, Zhao RQ, Li JX, Tan ZL 2007: Effect of early feed restriction on metabolic programming and compensatory growth in broiler chickens. Br Poult Sci 86: 654-660 